\title{
Applied philosophy of language
}

Book

Published Version

Creative Commons: Attribution 4.0 (CC-BY)

Open Access

Borg, E. ORCID: https://orcid.org/0000-0003-2725-9568, Fisher, S. A. ORCID: https://orcid.org/0000-0003-1115-6134, Hansen, N., Scarafone, A. and Shardimgaliev, M. (2020) Applied philosophy of language. Ratio, 33 (4). Wiley. doi: https://doi.org/10.1111/rati.12269 Available at https://centaur.reading.ac.uk/91124/

It is advisable to refer to the publisher's version if you intend to cite from the work. See Guidance on citing.

Published version at: https://doi.org/10.1111/rati.12269

To link to this article DOI: http://dx.doi.org/10.1111/rati.12269

Publisher: Wiley

All outputs in CentAUR are protected by Intellectual Property Rights law, including copyright law. Copyright and IPR is retained by the creators or other copyright holders. Terms and conditions for use of this material are defined in the End User Agreement.

www.reading.ac.uk/centaur

\section{CentAUR}

Central Archive at the University of Reading

Reading's research outputs online 


\section{Introduction}

\section{Emma Borg (i) | Sarah A. Fisher (i) | Nat Hansen (i) | Antonio Scarafone (1) | Marat Shardimgaliev}

Department of Philosophy, University of Reading, Whiteknights Campus, Reading, RG6 6AH, UK

Correspondence:

Marat Shardimgaliev, Department of Philosophy, University of Reading, Whiteknights Campus, Reading RG6 6AH, UK. Email: m.shardimgaliev@pgr.reading.ac.uk

This special issue of Ratio concerns the practical application of concepts and theories developed in philosophy of language. Recent examples of applied philosophy of language include work showing how the illocutionary and perlocutionary effects of speech helps us understand political propaganda (Stanley, 2015), hate speech (Langton, 2018), and pornography (Hornsby et al., 2011; Langton \& West, 1999; Saul, 2006). And analyses of the semantics and pragmatics of slurring expressions have deepened our understanding of the moral implications of using these terms (for a survey of recent work, see the collection edited by Sosa (2018)). The papers collected in this special issue expand the scope of applied philosophy of language on a number of fronts.

In 'The big shill', Eliot Michaelson \& Robert Simpson address the phenomenon of 'shilling', i.e., being paid to speak in support of a product, organisation, or cause. They seek to pinpoint what makes this practice distinctively objectionable-a task which is made more important by the expanding role of social media 'influencers'. The authors argue that the wrongness of shilling does not inhere in the shill's insincerity, epistemic negligence, or propensity to produce bad consequences. Instead, by blurring the distinction between personal and 'clerical' speech, shilling undermines our wider communicative practice.

The article by Teresa Marques concerns 'bald-faced lies', which are uttered despite their falsity being common knowledge between speaker and audience. Contrary to other analyses, Marques argues that bald-faced lies are still asserted and are still morally wrong-specifically, because of the way in which they exploit the norms of assertion. Marques shows how her approach can capture our intuitive reactions to various case studies, including our inclinations to disagree with-and disapprove of-bald-faced liars. She uses her analysis to illuminate the pervasive problem of 'gaslighting', whereby liars cause their audiences to doubt their own knowledge.

Endre Begby's contribution emphasises the importance of assessing alternative norms of assertion from the point of view of non-ideal conversational contexts, and on these grounds challenges Timothy Williamson's (2000) Knowledge Norm of Assertion. According to Williamson, it is a constitutive norm of assertion that one asserts that $p$ only if one knows that $p$. This norm, Begby argues, lends itself to a specific kind of strategic weaponisation: if the Knowledge Norm of Assertion is in the common ground, then in certain contexts speakers might be forced to retract an assertion without any discussion of its merits. In some antagonistic contexts, the Knowledge Norm of

This is an open access article under the terms of the Creative Commons Attribution License, which permits use, distribution and reproduction in any medium, provided the original work is properly cited.

(c) 2020 The Authors. Ratio published by John Wiley \& Sons Ltd 
Assertion can thus be exploited to silence an opponent without having to consider the reasons they might offer in support of an asserted proposition.

Some generic sentences, such as 'no religion condones the killing of innocents', might be uttered with the aim of establishing or reinforcing the truth of the asserted content, even when there are evident deviations from it. Kathryn Lindeman calls these utterances 'conservatives', and argues that constitutive conservatives, namely conservative utterances that partly constitute the truth of the asserted content, play a crucial role in enforcing norms and values within social groups.

In 'What use has approved', Timothy Endicott defends the idea that the meaning of a word is given by a customary rule for its use and discusses the implications of this idea for legal interpretation. He defends his view of word meaning on the basis of a comparison between customary rules in language and customary rules in law. Endicott's proposal is to think of both types of customary rules in terms of the 'service' that they provide. This service conception of rules, he argues, can help us in addressing important puzzles about customary rules, relating to questions of normativity and disagreement.

Alexis Burgess's \& David Plunkett's paper develops a new account of conceptual engineering, i.e., the practice of attempting to improve concepts, words and other representational devices that we use in thought and communication. Conceptual engineering has not only been a central topic in recent debates on philosophical methodology but also has important practical implications, for instance for our use of concepts and terms relating to gender and race. Burgess \& Plunkett propose that conceptual engineering is intimately linked to three activities: conceptual ethics, conceptual innovation, and conceptual implementation. They try to cash out how we should think of the nature of this relationship and they defend their view against alternative conceptions.

Directly related to considerations of conceptual engineering and conceptual ethics is Derek Ball's paper 'Metasemantic ethics'. Here, he discusses ethical questions relating to the fact that experts have a privileged role in determining the meaning of certain words that we use in ordinary conversations and specialized discourse. An example is the privileged role of doctors in determining the meaning of terms such as 'arthritis' or 'homosexuality'. Ball shows that there is a variety of ways in which the determination of such terms by experts might be morally problematic. He also shows how this insight relates to different metasemantic theories and provides useful distinctions for further research in metasemantic ethics.

Ashley Feinsinger \& David Friedell offer a reflection on the harm that can be done in labelling medicalised conditions and the individuals that have those conditions. Among the many things that we do with language is our use of it to negotiate the expressions that refer to ourselves, and this capacity has both an instrumental and intrinsic value. Feinsinger \& Friedell argue that medical labelling done without the participation of those who will receive the label, as well as failure to take into account demands for renegotiating the label, are either harmful or wrongful because they hinder individuals' linguistic agency without any good reason, and this hindering can be a case of systematic injustice.

Taken together, these papers provide an innovative and exciting exploration of some of the many ways in which philosophy of language can be applied to pressing social and practical issues. We hope, therefore, that the volume as a whole will contribute to furthering understanding and stimulating new research in this important area.

Three of the papers in this issue, by Derek Ball, Timothy Endicott, and Teresa Marques, were presented at the 2019 Ratio conference. The other five papers, by Endre Begby, Ashley Feinsinger \& David Friedell, Kathryn Lindeman, Eliot Michaelson \& Robert Simpson, David Plunkett \& Alexis Burgess, were commissioned for the special issue.

Alongside our contributors, we would like to thank the other participants in the conference, especially Åsa Wikforss and our seven poster presenters: Elsa Brisinger, Georgia Brown, Anna Drożdżowicz, Amanda McMullen, Julio Pohl, Martina Rosola, and Xuan Wang. The conference would not have been possible without the generous support of our funders: the Analysis Trust, The Aristotelian Society, The Mind Association, the South, West and Wales Doctoral Training Partnership, and the University of Reading's Centre for Integrative Neuroscience and Neurodynamics. Thanks are also due to David Oderberg for his invaluable support, both with the organisation of 
a successful conference and with the publication of this special issue. Finally, we would like to thank Eva van Herel and Luke Thompson for their administrative support.

\section{ORCID}

Emma Borg (iD https://orcid.org/0000-0003-2725-9568

Sarah A. Fisher (iD https://orcid.org/0000-0003-1115-6134

Nat Hansen (iD https://orcid.org/0000-0001-5074-1075

Antonio Scarafone (iD https://orcid.org/0000-0002-6044-6325

Marat Shardimgaliev (iD) https://orcid.org/0000-0001-7826-6632

\section{REFERENCES}

Hornsby, J., Antony, L. M., Saul, J. M., Stoljar, N., Wieland, N. C., \& Langton, R. H. (2011). Subordination, silencing, and two ideas of illocution. Jurisprudence, 2, 379-440. https://doi.org/10.5235/204033211798716826

(2018). The authority of hate speech. In J. Gardner, L. W. Green, \& B. Leiter (Eds.), Oxford Studies in philosophy of law (Vol. 3, pp. 123-152). Oxford, UK: Oxford University Press.

Langton, R. H., \& West, C. (1999). Scorekeeping in a pornographic language game. Australasian Journal of Philosophy, 77, 303-319. https://doi.org/10.1080/00048409912349061

Saul, J. M. (2006). Pornography, speech acts and context. Proceedings of the Aristotelian Society, 106, 229-248.

Sosa, D. (Ed.). (2018). Bad words: Philosophical perspectives on slurs. Oxford, UK: Oxford University Press.

Stanley, J. (2015). How propaganda works. Princeton, NJ: Princeton University Press.

Williamson, T. (2000). Knowledge and its limits. Oxford, UK: Oxford University Press.

How to cite this article: BorgE, Fisher SA, Hansen N, Scarafone A, Shardimgaliev M. Introduction. Ratio. 2020;00:1-3. https://doi.org/10.1111/rati.12269 